1 Bell J. Hereditary optic atrophy. In: Pearson K, ed. The treasury of human inheritance. London: Cambridge University Press, 1933; vol 2, part 4: 325-425.

2 Rogers JA. Leber's disease. Australian fournal of Ophthalmology 1977;5: 111-9.

s Carroll WM, Mastaglia FL. Leber's optic neuropathy: a clinical and visual evoked potential study of affected and asymptomatic members of a six generation family. Brain 1979;102:559-80.

4 Morlet C. Hereditary optic atrophy as a possible menace to the community. Med $\mathcal{F}$ Aust $1921 ; 11: 499-502$.

- King EF. Leber's disease in twins. Proc $R$ Soc Med 1939;32:763-4.

- Lees F, MacDonald AME, Turner JWA. Leber's disease with symptoms resembling disseminated sclerosis. F Neurol Neurosurg Psychiatry 1964; 27:415-21.

7 Nikoskelainen E, Sogg RL, Rosenthal AR, Friberg TR, Dorfman LJ. The early phase in Leber hereditary optic atrophy. Arch Ophthalmol 1977; 95:969-78.

8 Smith JL, Hoyt WF, Susac JO. Ocular fundus in acute Leber optic neuropathy. Arch Ophthalmol 1973;90:349-54.

- Perkin GD, Rose FC. Optic neuritis and its differential diagnosis. London: Oxford University Press, 1979.

10 Wilson J. Leber's hereditary optic atrophy: a possible defect of cyanide metabolism. Clinical Science 1965;29:505-15.

11 Wallace DC. A new manifestation of Leber's disease and a new explanation for the agency responsible for its unusual pattern of inheritance. Brain $1970 ; 93: 121-32$.

12 Wilson J. Skeletal abnormalities in Leber's hereditary optic atrophy. Ann Phys Med 1965;8:91-5.

13 Adams JH, Blackwood W, Wilson J. Further clinical and pathological observations in Leber's optic atrophy. Brain 1966;89:15-26.

14 Oud JSF, Henneman IP, Brugge RJ, et al. La maladie de Leber. Etude anatomique de deux cas dans une fratrie. $\mathcal{F}$ Neurol $S c i$ 1968;6:401-17.

15 Halliday AM, McDonald WI, Mushin J. Visual evoked potentials in patients with demyelinating disease. In: Desmedt JF, ed. Visual evoked potentials in man: new developments. London: Oxford University Press, 1976:438-49.

16 Halliday AM, Halliday E, Kriss A, McDonald WI, Mushin J. The patternevoked potential in compression of the anterior visual pathways. Brain 1976;99:357-74.

17 Dorfman LJ, Nikoskelainen E, Rosenthal AR, et al. Visual evoked potentials in Leber's hereditary optic neuropathy. Ann Neurol 1977;1:565-8.

18 Fine PEM. Mitochondrial inheritance and disease. Lancet 1978;ii:659-61.

19 Harper PS. Mendelian inheritance of transmissible agent ? The lesson of Kuru and the Australia antigen. $\mathcal{F}$ Med Genetics 1977;14:389-98.

\section{Spina bifida and the sex ratio}

Does the disturbed sex ratio often seen in spina bifida and anencephaly suggest that a gene on the $\mathrm{X}$ chromosome plays a part? For some years these conditions have been regarded as examples of "threshold defects" - that is, defects of multiple causation in which the inherited contribution is mediated by more than one gene and the number of genes required for the disease to develop varies according to the strength of the environmental factors. There is ample justification for this view. ${ }^{12} \mathrm{~A}$ recent article by Burn and Gibbens ${ }^{3}$ put forward the subsidiary hypothesis that in spina bifida the disturbance of the sex ratio (though not, as the title misleadingly suggests, the disease itself) may be related to an X-linked gene that interferes with the natural loss of affected fetuses. One strand of evidence they cite is the inverse correlation in the valleys of South Wales between the incidence of spina bifida and of spontaneous abortion. ${ }^{4}$

Certainly sex is important in the aetiology of spina bifida. In populations with a high risk of neural tube defects there is a pronounced excess of affected females, ${ }^{5}$ and when one case has occurred in a family there is a high risk of neural tube defects in the maternal half-sibs and in the mother's sisters' offspring. ${ }^{6}$ The risk is higher, too, in offspring of mixed marriages where the mother but not the father is from a higher-risk population-but not vice versa. ${ }^{7}$

Burn and Gibbens postulate that spontaneous abortion of fetuses with neural tube defects is inhibited by a mechanism at the deciduo-placental junction under the control of a single dominant mutant gene on the $\mathrm{X}$ chromosomes of mother or fetus or both. In this way there could be up to four copies of the mutant gene, the extreme case being a mother homozygous for the gene carrying a female fetus with two mutant genes. They argue that the more severe the defect, and thus the greater the number of these genes needed for survival (that is, to prevent miscarriage), the greater will be the proportion of females among survivors. An "epidemic" of all-female anencephalic infants would suggest a particularly severe form of malformationthe affected male fetuses having all been aborted, lacking the protection of four mutant genes.

Burn and Gibbens did not, however, test the application of their hypothesis to spina bifida by pedigree studies or animal experiments. Instead the authors set out a simple table of the expected proportions of offspring and parental genotypes for any X-linked gene if the system is in Hardy-Weinberg equilibrium, and illustrated it with a numerical example. Their calculations ignore the fact that if the hypothesis is correct a factor to represent the presumed selective advantage of the gene must be included in the equations. Goodness of fit to Hardy-Weinberg expectations based on genetic equilibrium in a population can on its own prove no hypothesis about mode of inheritance, and certainly in the present case there are far too many possible variables - gene frequencies, selection coefficients, genetic structure of the population-for any theory to be tested.

One of the oldest misconceptions in human genetics is to confuse X-linked inheritance with sex limitation and erroneously to implicate a gene on the $\mathrm{X}$ chromosome for conditions where females are more frequently affected than males. Classic examples of sex limitation are the short stature and lower digital ridge count in women. Hormonal and other. chemical differences between men and women may affect the threshold requirement for a trait not determined by the $\mathbf{X}$ chromosome. This, however, is a possibility the authors do not discuss.

Admittedly Burn and Gibbens recognise the need for family studies, but in their absence we are left with one more skeleton in an area littered with the bones of too many insufficiently tested hypotheses. To show by classroom example that disturbance of the sex ratio may be brought about by an Xlinked gene in the genotype of the mother or fetus or both is a long way from proving that such a mechanism is indeed at work in spina bifida and anencephaly. If the theory of Burn and Gibbens should turn out to be correct the practical importance would be that family studies could help to identify women at risk of producing a child with a neural tube defect. This speculation does not deserve to be taken seriously, however, until the necessary pedigree or experimental data have emerged.

1 Carter CO. Multifactorial inheritance revisited. In: Fraser FC, McKusick VA, Robinson R, eds. Congenital malformations. Amsterdam: Excerpta Medica, 1970:227-32.

2 Carter CO. Genetics of common single malformations. Br Med Bull 1976; 32:21-6.

3 Burn J, Gibbens D. May spina bifida result from an X-linked defect in a selective abortion mechanism ? F Med Genetics 1979;16:210-4.

- Roberts CJ, Lloyd S. Area differences in spontaneous abortion rates in South $W$ ales and their relation to neural tube defect incidence. $\mathrm{Br} \mathrm{MedF}$ 1973 ;iv :20-2.

5 Carter CO. Clues to the aetiology of neural tube malformations. Develop Med Child Neurol. 1974 ;16:suppl 32, 3-15.

- Yen S, Macmahon B. Genetics of anencephaly and spina bifida? Lancet 1968;ii:623-6.

7 Leck I. The etiology of human malformations : insights from epidemiology. Teratology 1972;5:303-14. 